\title{
Optimizing Groundwater Aquifers Potential in The Development of Irrigation Wells for Agriculture Using Geo-Electrical Method
}

\author{
Rustadi $^{1}$, O T Purwadi², I G B Darmawan ${ }^{1 *}$ \\ ${ }^{1}$ Department of Geophysical Engineering, Faculty of Engineering, Universitas Lampung, Bandar Lampung, Indonesia \\ ${ }^{2}$ Department of Civil Engineering, Faculty of Engineering, Universitas Lampung, Bandar Lampung, Indonesia \\ *Email: igedeboy@staff.unila.ac.id
}

\begin{tabular}{|c|c|}
\hline Article Information: & Abstract \\
\hline $\begin{array}{l}\text { Received: } \\
10 \text { March } 2020\end{array}$ & $\begin{array}{l}\text { The identification of shallow groundwater aquifers is demanded to sustain the balance } \\
\text { of utilization in agriculture and anticipate frictions that can occur due to the } \\
\text { overlapping usage of groundwater resources. This study is aimed to identify the }\end{array}$ \\
\hline $\begin{array}{l}\text { Received in revised form: } \\
2 \text { May } 2020\end{array}$ & $\begin{array}{l}\text { potential of groundwater resources based on the thickness and depth of the } \\
\text { groundwater aquifer. Geoelectric resistivity methods have done with vertical electrical } \\
\text { sounding (VES) and horizontal profiling techniques ( } 2 D \text { mapping). The VES data }\end{array}$ \\
\hline $\begin{array}{l}\text { Accepted: } \\
5 \text { May } 2020\end{array}$ & $\begin{array}{l}\text { acquisition was carried out with a Schlumberger array while } 2 D \text { mapping by alpha } \\
\text { Wenner array. Inversion results of vertical electrical sounding (VES) show that } \\
\text { groundwater resistivity values in sedimentary rocks ranged from } 1 \text { to } 100 \Omega m \text { and in } \\
\text { igneous rocks between } 0.5-150 \Omega m \text {. The results of } 2 D \text { Resistivity Mapping also show }\end{array}$ \\
\hline $\begin{array}{l}\text { Volume } 2 \text {, Issue } 1 \text {, June } 2020 \\
\text { pp. } 43-52\end{array}$ & $\begin{array}{l}\text { that shallow aquifer depth ranged from } 1 \text { to } 5 \mathrm{~m} \text { with a thickness ranged from } 15 \mathrm{~m} \text { to } \\
\text { more than } 70 \mathrm{~m} \text {. Meanwhile, bedrock depth ranged from } 20 \text { to } 150 \mathrm{~m} \text { with a pattern } \\
\text { deeper to the west. Furthermore, the potential of groundwater aquifers in the }\end{array}$ \\
\hline (C) Universitas Lampung & $\begin{array}{l}\text { development of irrigation wells for agriculture should be carried out in the western part } \\
\text { of the study area. }\end{array}$ \\
\hline $\begin{array}{l}\text { http://dx.doi.org/ } \\
10.23960 / \text { jesr.v2i1.43 }\end{array}$ & $\begin{array}{l}\text { Keywords: Groundwater, Shallow Aquifer, Rock Resistivity, Irrigation Well, Geo- } \\
\text { Electrical Sounding. }\end{array}$ \\
\hline
\end{tabular}

\section{INTRODUCTION}

$\mathrm{K}^{\mathrm{r}}$ rawangsari is a small area in the Ambarawa subdistrict, Pringsewu District, Lampung Province, Indonesia which produces clean water sources for drinking water needs to be known as "Krawang Water" [1] The water is produced from groundwater wells by the several refill water home industries with the average total production capacity reaching 520000 liters/day. The flow of water from the well reaches an average of 2 liters/second.

Krawangsari's surrounding area is agricultural lands, mostly semi-productive rainfed ricefields. This land only can be planted during the rainy season by utilizing water sources that come from rain. Overall, the agricultural area reaches 300 ha, which is managed by approximately 1300 farmers. They have tried to increase crop production by utilizing the transition period of the rainy season to the dry season. However, climate uncertainty has caused the effort to fail and crops drought.
Some farmers have tried to get water sources from groundwater. They make shallow wells on agricultural land independently. Farmer uses the well to meet water needs during the dry season for horticultural crops. Even so, some drilling sites for groundwater wells have failed. Successful well also has decreased water discharge [2]. This condition is a contrast between the production of raw water in Krawangsari and the surrounding agricultural land.

An alliance between domestic raw water, irrigation of agricultural land, and refill water-based home industries in Krawangsari-Ambarawa could be a source of future conflict. Consequently, gradual studies are needed to maintain the continuity of groundwater resources and the equal distribution of their use, one of which is to map groundwater aquifers [3].

The geoelectrical is one of many geophysical methods used for various groundwater exploration, including groundwater aquifer mapping [4]-[8]. Among them, Vertical Electrical Sounding (VES) and 
horizontal profiling techniques (2-Dimension or 2D Mapping) is the simplest method in groundwater exploration using geophysical surveys [9]. This technique can determine the depth and thickness of groundwater aquifer systems based on the electrical properties of rocks [8], [10], [11].

This study focused on mapping shallow groundwater aquifers using geoelectrical methods with VES and 2D mapping. This study also aims to determine the potential of groundwater resources as a source of water for agricultural land around the Krawangsari area. The results of this mapping are expected to be able to determine the exact location of the well and study material to build a groundwaterbased agricultural irrigation system.

\section{Materials AND MethodS}

Geographically, the location of the study (Fig. 1) is at coordinates (x, y) (496170 - 496762, 94025219401909) UTM zone 48S. The data used in this study came from observational data and geological maps and geoelectric measurements directly at the study site.

\section{A. Geological Settings}

Geologically, the study area is in a rock formation dominated by volcanic tuff material deposits (Lampung Tuffs Fm.). These Pliocene-Pleistocene rock materials are composed of tuffaceous sandstone, tuffaceous claystone, and pumiceous tuff [12], [13]. This rock surrounded by Quaternary sediment deposits as a product of sedimentation from the results of rock erosion in higher geomorphological conditions. Quaternary volcanic rocks are the youngest volcanic rocks found around the research area. This rock is the result of past activities from Mount Betung, Mount Pesawaran (Ratai), and Mount Sulah, which is eastsoutheast to the south. The rock composition dominated by andesite-basal breccia, lava, and tuff [12].

In the southern part of the study site, there is a Cretaceous (Menanga Fm.) Rock Formation in the form of interbedding between shales, claystones, and sandstones with flint inserts and limestone lenses [12]. Some rock outcrops in the form of marble also can be observed around the research area. It cannot confirm whether this marble originated from changes in rock from this formation or part of the oldest rock formations in this area. The oldest rocks that exposed around the study site were Paleozoic rocks (Gunungkasih Fm) with the main composition of quartzite and partially marble and schist [12], [14], [15]. However, the location of the marble outcrops of this formation is far north-northwest.

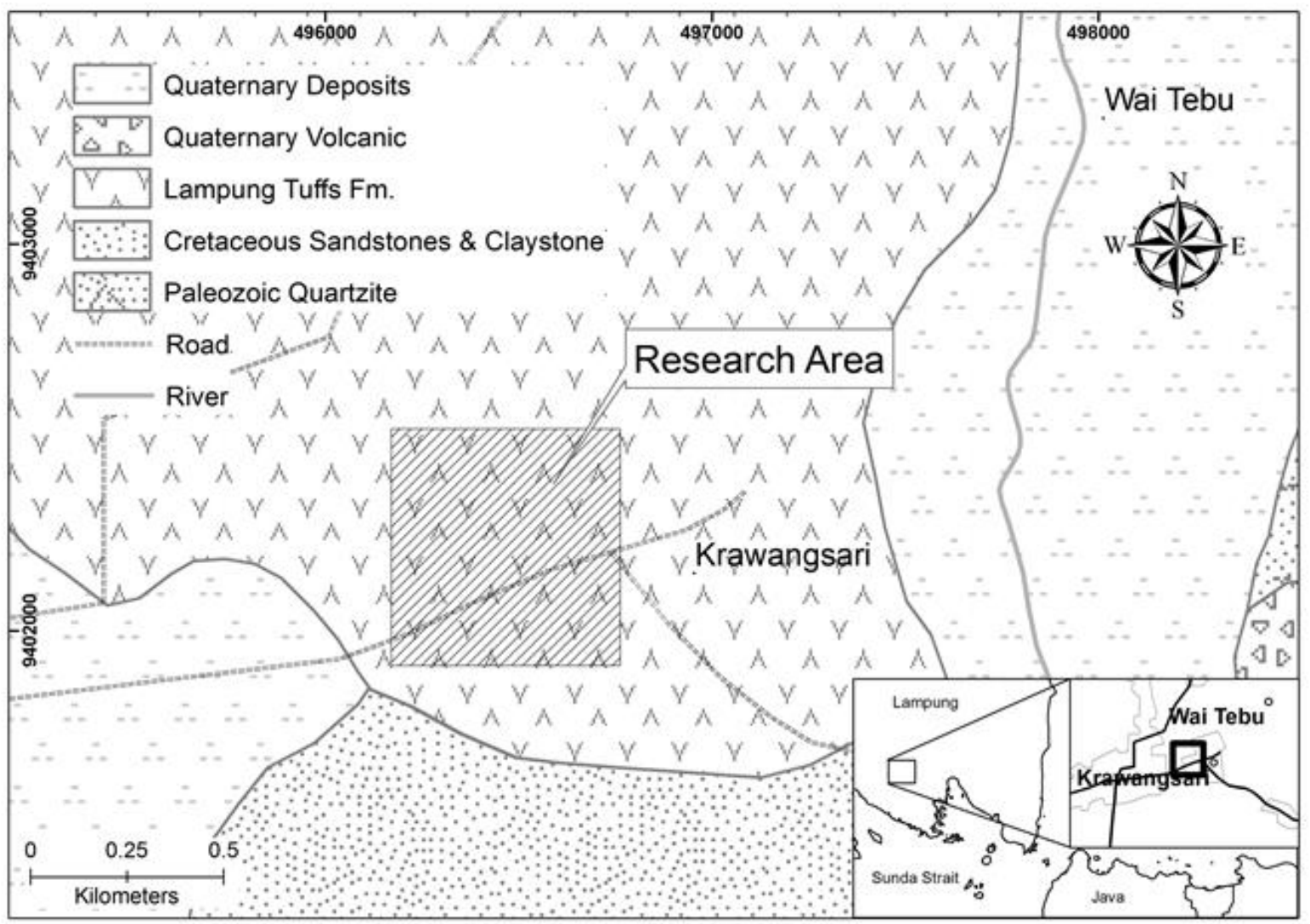

Figure 1. Research areas that show the Krawangsari geology and surrounding areas. The research area indicated by a box with a striped pattern. There is a five of rock formation from the Paleozoic to the Quaternary (modified after [12]). 


\section{B. Geoelectrical Resistivity Aquisition}

Geoelectric resistivity data acquisition was carried out using the Naniura resistivity meter for VES and ARES resistivity meter for $2 \mathrm{D}$ mapping. The resistivity geoelectric method is a method of measuring the electrical properties of subsurface rocks by injecting an electric current into the earth and measuring the potential magnitude produced. The geoelectrical method consists of four electrodes aligned and separated inline with some configuration, i.e., Wenner and Schlumberger. Both Wenner and Schlumberger array has two potential electrodes and two current electrodes. Wenner Wenner has equal spacing between the electrodes [16], [17]. Meanwhile, Schlumberger has twice or more spacing between the potential electrode to the current electrode [18], [19].

Vertical Electrical Sounding (VES): is a 1D acquisition method with a target of rock resistivity values vertically. VES data acquisition of 18 points scattered randomly in the study area (Fig. 2), was carried out with a Schlumberger array as the most popular configuration for this method [20], [21]. The stretch of the current electrode ( $\mathrm{AB} / 2$ ), ranging from $1.5 \mathrm{~m}$ to $225 \mathrm{~m}$. This method is used to measure the resistivity value at the measurement point by optimizing it vertically.

Horizontal Profiling (2D Mapping): is a 2D acquisition method with target values of rock resistivity vertically and horizontally. 2D data acquisition is carried out in 4 paths ( $\mathrm{Kr}-\mathrm{L}$ line) with Alpha Wenner electrode configurations (Fig. 2). The maximum length of the electrode stretch is $225 \mathrm{~m}$, while the smallest electrode spacing is $5 \mathrm{~m}$. This method is used to complete the distribution of resistivity value data horizontally.

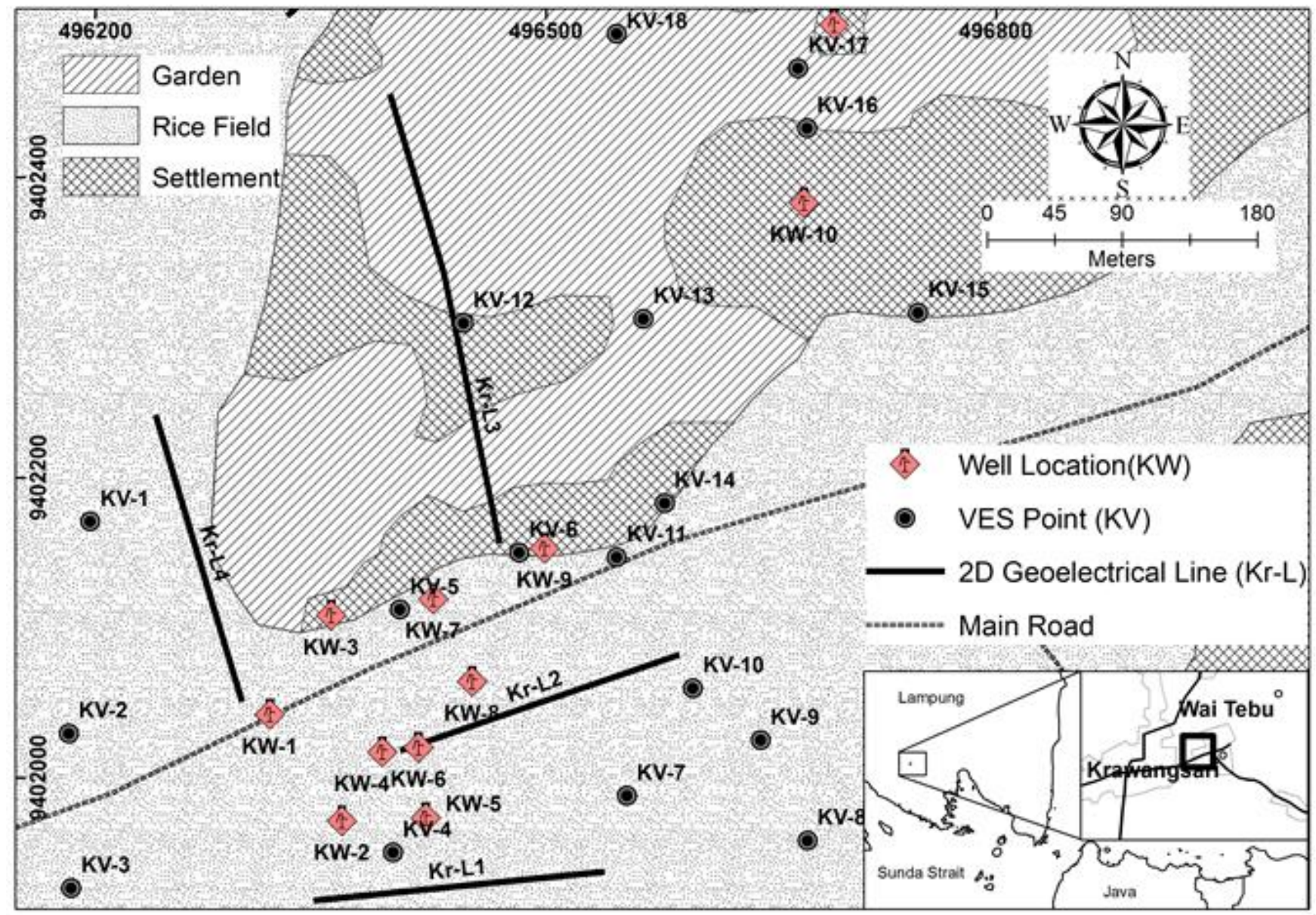

Figure 2. A circle with a black dot indicating the point of measurement of vertical electrical sounding (VES) and a 2D Mapping track marked with a firm black line. The location of groundwater wells marked with a red symbol.

Data from VES and 2D Mapping measurements are apparent resistivity values. The apparent resistivity is inverted using IPI2Win for VES data [22], [23] and RES2DINV for 2D resistivity data inversion. RES2DINV has a well-assessed algorithm to get the actual resistivity value and resistivity layer model. The depth and thickness of the groundwater aquifer are obtained based on the interpretation of the resistivity layer model.

The least-squares inversion method with smoothness constraints is used to inverse all 2D paths. This method tries to minimize the difference between measured resistivity values and resistivity values calculated [24]. Each inversion is performed with 
optimal iteration to get the smallest RMS error value.

\section{RESUlTS AND DISCUSSIONS}

Analysis of field acquisition data using the VES and 2D Mapping methods that have been processed and inverted expose the location of the presence of shallow groundwater aquifers.

\section{A. 1D Inversion Analysis}

The 18 point inversion results of vertical electrical sounding (VES) data showed the depth and thickness variations of shallow aquifers (Table 1). According to [25], groundwater resistivity values in sedimentary rocks ranging from $1-100 \Omega \mathrm{m}$ and in igneous rocks between $0.5-150 \Omega \mathrm{m}$. Modeling using a minimum of three layers shows that the average aquifer potential is in the second layer. However, some layers did not show any potential for shallow aquifers.

Table 1. Summary of Ves Resistivity Model Values and Their Corresponding Thicknesses

\begin{tabular}{lcccccccc}
\hline \multirow{2}{*}{$\begin{array}{l}\text { VES } \\
\text { Point }\end{array}$} & \multicolumn{2}{c}{ Layer 1 } & \multicolumn{2}{c}{ Layer 2 } & \multicolumn{3}{c}{ Layer 3 } & \multicolumn{2}{c}{ Layer 4 } \\
& $\begin{array}{c}\text { Resistivity } \\
(\Omega \mathrm{m})\end{array}$ & $\begin{array}{c}\text { Thickness } \\
(\mathrm{m})\end{array}$ & $\begin{array}{c}\text { Resistivity } \\
(\Omega \mathrm{m})\end{array}$ & $\begin{array}{c}\text { Thickness } \\
(\mathrm{m})\end{array}$ & $\begin{array}{c}\text { Resistivity } \\
(\Omega \mathrm{m})\end{array}$ & $\begin{array}{c}\text { Thickness } \\
(\mathrm{m})\end{array}$ & $\begin{array}{c}\text { Resistivity } \\
(\Omega \mathrm{m})\end{array}$ & $\begin{array}{c}\text { Thickness } \\
(\mathrm{m})\end{array}$ \\
\hline $\mathrm{KV}-1$ & 17.8 & 12.7 & 2.47 & 20.3 & 47000 & - & - & - \\
$\mathrm{KV}-2$ & 7.01 & 1.85 & 53 & 4.23 & 5.05 & 7.69 & 128 & 11.4 \\
$\mathrm{KV}-3$ & 5.95 & 1.24 & 6.32 & 143 & 20000 & - & - & - \\
$\mathrm{KV}-4$ & 0.65 & 1.31 & 367 & 2.66 & 15652 & - & - & - \\
$\mathrm{KV}-5$ & 8.69 & 2.14 & 0.77 & 1.72 & 15000 & - & - & - \\
$\mathrm{KV}-6$ & 14 & 2.21 & 40.2 & 2.23 & 4.83 & 3.13 & 53.3 & 11.3 \\
$\mathrm{KV}-7$ & 62.3 & 4.92 & 106 & 27.3 & 31.4 & 34.8 & 569 & - \\
$\mathrm{KV}-8$ & 24.7 & 2.14 & 2.45 & 6.37 & 14000 & - & - & - \\
$\mathrm{KV}-9$ & 191 & 3.12 & 1167 & 15.2 & 12 & 32.8 & 1340 & - \\
$\mathrm{KV}-10$ & 1.14 & 1.5 & 677 & 4.83 & 39000 & - & - & - \\
$\mathrm{KV}-11$ & 4.54 & 0.42 & 12.1 & 2.08 & 0.56 & 3.73 & 19000 & - \\
$\mathrm{KV}-12$ & 883 & 1.79 & 186 & 1.68 & 1884 & 14.8 & 28.8 & - \\
$\mathrm{KV}-13$ & 120 & 1.2 & 171 & 19.8 & 920 & 14.1 & 3.05 & - \\
$\mathrm{KV}-14$ & 108 & 4.04 & 5.2 & 15.6 & 116 & 25.5 & 2820 & 106 \\
KV-15 & 108 & 4.03 & 5.2 & 15.3 & 385 & 30.5 & 404 & - \\
KV-16 & 111 & 1.22 & 308 & 9.84 & 1463 & 10.5 & 1.72 & - \\
KV-17 & 93.5 & 0.92 & 364 & 5.89 & 2198 & 10.8 & 84.9 & - \\
KV-18 & 197 & 0.7 & 1184 & 9.12 & 357 & 4.21 & 1710 & 20.3 \\
\hline
\end{tabular}

The examples of plotted images of pseudoresistivity curves for 1D layered resistivity modeling (Fig. 3) show potential aquifers at layer 2 and layer 4 . This model

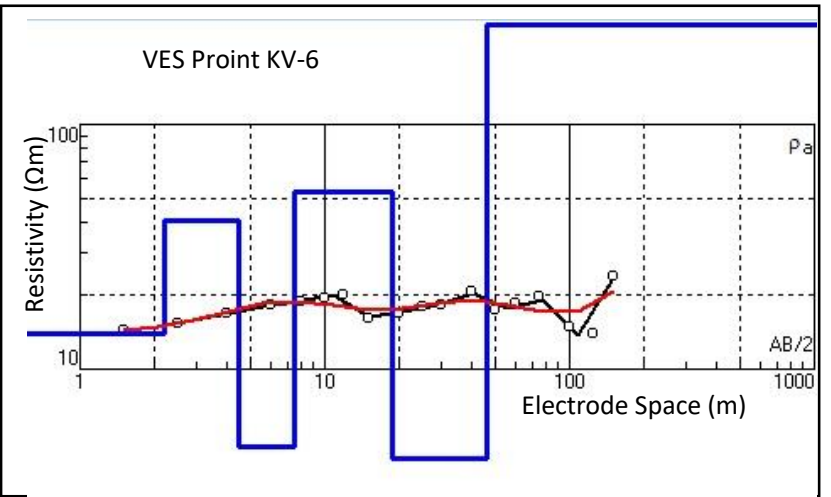

Figure 3. The results of the plot of apparent resistivity curves at the KV-6 point of VES data.

shows that there is a reasonably thick aquifer potential, for example, from layer 2 to layer 4 . The aquifer resistivity values at point KV-6 ranged from 4 to 53 $\Omega \mathrm{m}$. The depth of the aquifer ranges from 2 meters to
46 meters, with a thickness of aquifers around 44 meters. Nevertheless, VES data have not been able to detect the presence of bedrock. Therefore, it is possible to find a larger aquifer thickness.

Pseudo resistivity plot curves show the different conditions at the KV-18 point (Fig. 4). It shows the apparent resistivity values are more than $100 \Omega$.

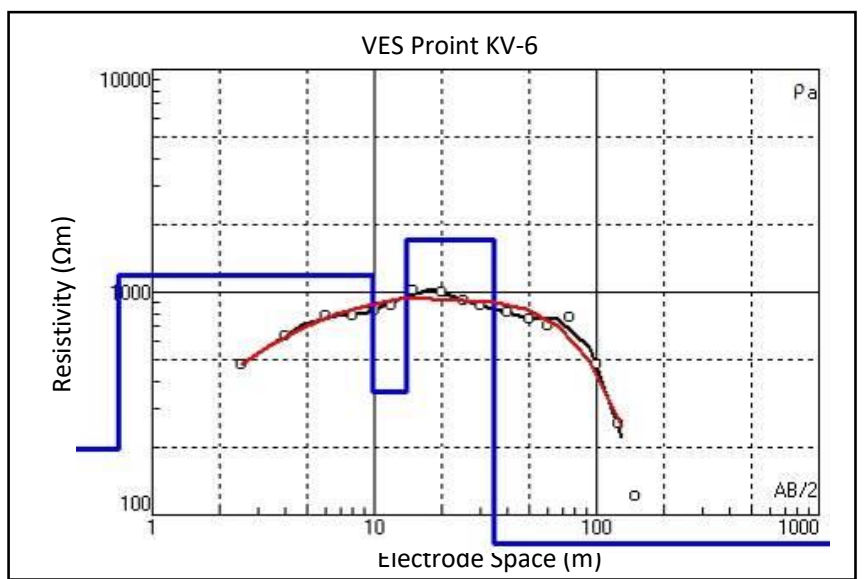

Figure 4. The results of the plot of apparent resistivity curves at the KV-18 point of VES data. 
However, the resulting plot curve does not indicate the existence of shallow aquifer potential. The resistivity value of the second layer after the topsoil in the first layer is $1184 \Omega \mathrm{m}$. High resistivity values indicating the layers of rock with greater density, the possibility of igneous rocks with low or dry water content, or bedrock close to the surface. However, the trend of resistivity values that continue to decline in line with depth also indicates the presence of depressed aquifer/aquifer potential. Therefore, it is necessary to re-measure the long stretch of the electrode $(\mathrm{AB} / 2)$.

Based on the all measurement data of VES has been inverted, the value of the resistivity zone of a shallow groundwater aquifer in the study area ranged between 0.5 - $200 \Omega$.

\section{B. 2D Inversion Analysis}

The inversion results from four 2D trajectories of resistivity mapping show a more obvious variation in horizontal and vertical resistivity values. The inversion rock resistivity values range from $3-25000 \Omega \mathrm{m}$. The pattern of resistivity layers shows a clear pattern related to the position of aquifers and bedrock. By using the same resistivity range with aquifer resistivity in the VES data, the depth and thickness of the shallow aquifer zone success to interpret.

The inversion results on the paths Kr-L1 and Kr-L2 (Fig. 5) show resistivity patterns which are dominated by bedrock with high resistivity values. This dominance starts at a depth of 12 to $33 \mathrm{~m}$ and continually consistent. Meanwhile, the location of shallow aquifers is right under the topsoil, with a thickness of thin aquifers ranging from 5-33 m.

The agricultural area in the southern part of the research location is the location of the $\mathrm{Kr}-\mathrm{L} 1$ and $\mathrm{Kr}$ L2 paths. Shallow aquifer conditions on the track characterized by resistivity values range between 30$150 \Omega \mathrm{m}$. This aquifer located between layers of clay on topsoil with resistivity values range between 1-30 $\Omega \mathrm{m}$ and rock pedestal at high resistivity value is more than $1000 \Omega \mathrm{m}$. The tendency of the bedrock body, which is more distant at the beginning of the trajectory, can be an indication of the potential for the thickening of the groundwater aquifer.

Investigations conducted in several community wells in the rice fields $(\mathrm{KW}-2, \mathrm{KW}-4, \mathrm{KW}-5, \mathrm{KW}-6$, KW-8) showed similar conditions. Some wells managed to get water at a depth of more than $10 \mathrm{~m}$. However, the amount of water that can be pumped from these wells very limited, especially in the dry season. Even when the investigation finished, the KW8 wells in dry conditions. This condition is related to the location of a very shallow aquifer, although it has the potential of sufficient aquifer thickness, the shallow position causes very generous climatic and seasonal influences on the ability of aquifers to hold water.

Different conditions can be observed in the inversion results of the path resistivity data $\mathrm{Kr}-\mathrm{L} 3$ and Kr-L4 (Fig. 5). Even though the Kr-L4 path shows a pattern similar to the previous two trajectories, a considerable decrease in the bedrock body increased the thickness of the shallow aquifer zone at the starting point of this path. The aquifer layer is estimated to be in the range of resistivity values $30-150 \Omega \mathrm{m}$. Meanwhile, in the topsoil layer, there are clay lenses with a spectrum of resistivity values between $1-10 \mathrm{~m}$. This condition also confirmed by the results of the 1D curve at the point of $\mathrm{KV}-1$, which has a thickness of up to $30 \mathrm{~m}$ for the range of resistivity values $<100$ $\Omega \mathrm{m}$

The potential shallow aquifer zone also detected by resistivity data on the Kr-L3 path. In the beginning area, this path shows a range of resistivity values of 40 - $250 \Omega \mathrm{m}$, which estimated as a potential groundwater aquifer. KW-9 and KW-7 wells in the vicinity of the area are wells that have successfully gotten groundwater, even able to survive during the dry season despite a decrease in discharge. The farther the distance from the beginning area of track $\mathrm{Kr}-\mathrm{L} 3$, the higher the resistivity values even reached more than $25000 \Omega \mathrm{m}$. This resistivity value estimated as the response of bedrock composed of igneous rock. The remains of igneous rock form a small hill known by the surrounding community as Bukit Krawang.

\section{Aquifer Distribution}

The distribution of shallow aquifers based on the results of the interpretation of aquifer data VES and 2D Resistivity Mapping layers showing aquifer patterns in two potential zones (Fig. 6). The first zone located at the location of the KW-9 well, which is a water source for Krawang Water. The thickness of aquifers in this zone ranges from $25-50 \mathrm{~m}$ even though the area is not large enough. This condition also strengthened by the adequate production of drinking water from these wells, and several experimental wells around it failed due to being outside the potential zone of groundwater aquifers. 


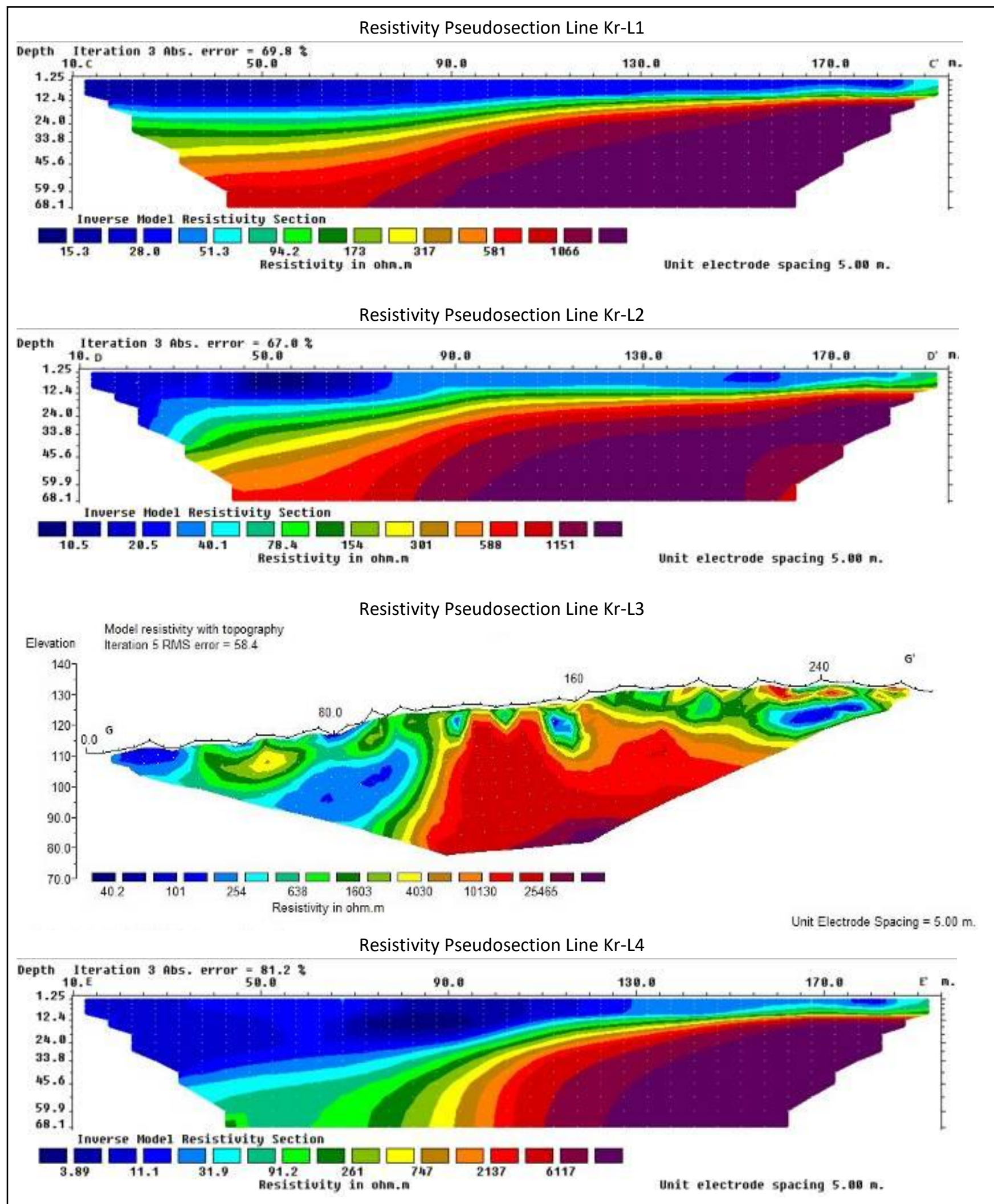

Figure 5. The results of 2D resistivity inversion on the Kr-L1 and Kr-L2 path (upper) show a very slim shallow aquifer pattern under the topsoil. On the Kr-L3 and Kr-L4 path (lower) shows the aquifer pattern is quite thick at the beginning of the track. The dominance of the rock response which has a high resistivity value estimated as bedrock.

The most potential aquifer zone is in the west area of the research location with a thickness of aquifers ranging from $15-75 \mathrm{~m}$ and a somewhat large area. Unfortunately, there are no wells that can be used to confirm the potential of aquifers in this region. There is no artesian well around the west area because most of the people built wells around the KW-9 well, even though most of them failed. 


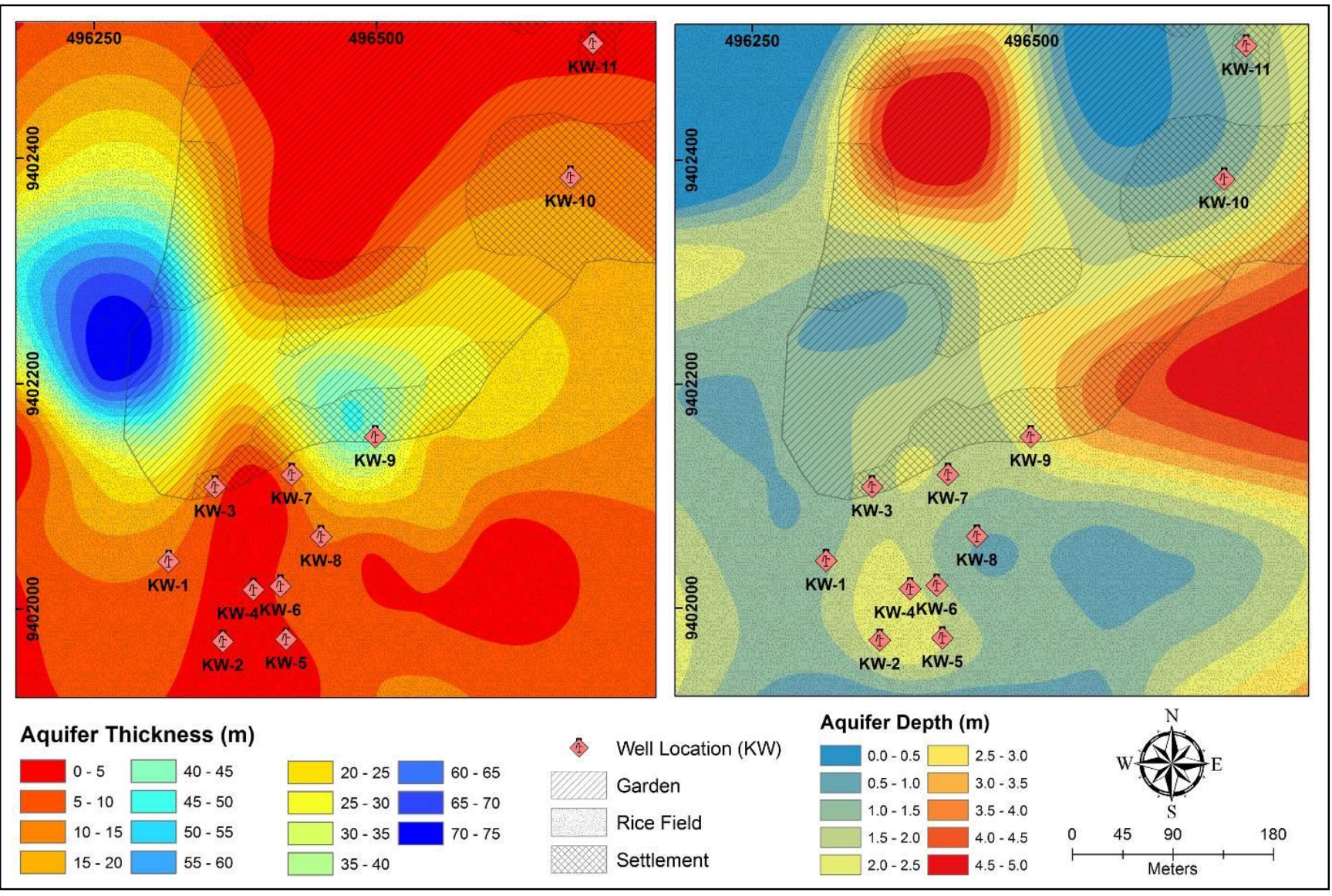

Figure 6. The potential zone distribution map shows shallow groundwater aquifer (VES) and 2D Mapping data interpretation for thickness (left) and depth (right) of the aquifer. Red to blue gradation color symbolize the thickness of the aquifer.

Based on the map of shallow aquifer thickness, it appears that the failure of farmers in making wells for agricultural needs is related to the thinness of shallow aquifers in the area. Most of the wells in the farm field are unable to meet irrigation needs, especially in the dry season. Therefore, the development of wells must begin to directed to the western part of the research area.

Based on the distribution map of aquifer depth, it shows that the wells made by the community follow contours that show shallow aquifers. This distribution dominates most of the study area, although there are areas that do not have shallow aquifers with red dominance characteristics on the map of the thickness and depth of the aquifer (Fig. 6). If it is related to the geological conditions of the study area, which are in tertiary volcanic rock formations, then the possibility of igneous rocks causes thin aquifer conditions.

\section{Discussion}

The use of geo-electrical sounding and 2D mapping methods can identify shallow aquifers quite well. The results of the identification of potential zones of groundwater aquifers are in the rice fields in the west and center of the research area. The first aquifer zone is in the KW-9 well area, which used as a drinking water production well. The success of the production well is related to its location right in the zone of the groundwater aquifer. This aquifer interpreted as a part of a sub-basin due to the geomorphological formation of the Krawang hill, which is thought to be an intrusive body. This interpretation is based on the results of interviews with several communities when they conducted well drilling.

Some wells that managed to get water during drilling, they found rocks in the form of sandstone mixed with claystone with the size of sand grains from fine to coarse. If it is associated with the geological conditions of the area with the dominance of volcanic tuff rocks on the surface, it is certainly not part of the formation that becomes an aquifer. Possible groundwater aquifers in this area are in deeper rock formations, namely cretaceous sandstone and claystone formations. To prove this assumption, drilling data from the drilling result certainly needed.

Another condition that also quite interesting to discuss is the area around the well KW-9, which has a reasonably good aquifer but only within a radius that is not too large. Some wells in the vicinity do not get the same water as in the KW-9 well. This condition also reinforced by the results of measurements of $2 \mathrm{D}$ 
resistivity mapping that form aquifer patterns in a small area. Are these aquifer patterns influenced by structures that are likely to develop around the area or sub-basin patterns produced by the presence of granite plutons in Krawang Hill? Both of these are debatable until supporting data can obtain that can prove it.

\section{CONCLUSIONS}

The current finding shows that the potential of groundwater aquifers in agricultural environments is found in the western region of Bukit Krawang, while in the south, it is not. This condition gives a strong indication of why residents irrigation wells in the southern part of Bukit Krawang failed. Therefore, by utilizing the results of mapping groundwater aquifers, the development of irrigation wells for agriculture should be carried out in the western part.

Based on the results of VES and 2D resistivity mapping, aquifer depth characteristics in the eastern part of Krawang Hill between $1-3 \mathrm{~m}$ for shallow aquifers with a thickness of aquifers between $15 \mathrm{~m}$ and more than $70 \mathrm{~m}$. The depth of the bedrock ranges from $50-150 \mathrm{~m}$, with a pattern more submerged into the west. While for aquifers in the southern part, it has a depth characteristic between $2-5 \mathrm{~m}$ for shallow aquifers with a thickness of aquifers ranging from 25 $50 \mathrm{~m}$ and the deepness of the bedrock between $20-70$ $\mathrm{m}$. With the potential of two separate aquifers, the water requirements for agricultural irrigation during the dry season can suffice, while aquifers for drinking water production wells in the south can still be sustainable.

\section{ACKNOWLEDGMENT}

We would like to thanks all teams who have assisted in the implementation of this research. Geophysical exploration laboratories, the University of Lampung has lent the tools and software for data processing.

\section{REFERENCES}

[1] A. Saputra, "Cerita Mata Air Karawang di Ambarawa Pringsewu Lampung | jejamo.com," 2015. [Online]. Available: https://www.jejamo.com/cerita-mata-air-karawangdi-ambarawa-pringsewu-lampung.html. [Accessed: 14-Jan-2020].

[2] R. D. Budiawan, "Debit Air Sumur Ambarawa Timur Turun, Warga Minta tak Tambah Sumur Bor Tribun Lampung," 2015. [Online]. Available: https://lampung.tribunnews.com/2015/04/08/debitair-sumur-ambarawa-timur-turun-warga-minta-taktambah-sumur-bor. [Accessed: 14-Jan-2020].

[3] F. J. Chang, C. W. Huang, S. T. Cheng, and L. C. Chang, "Conservation of groundwater from over-
exploitation-Scientific analyses for groundwater resources management," Sci. Total Environ., vol. 598, no. 15, pp. 828-838, 2017, doi: 10.1016/j.scitotenv.2017.04.142.

[4] A. A. Nigm, R. A. Elterb, F. E. Nasr, and H. M. Thobaity, "Contribution of Ground Magnetic and Resistivity Methods in Groundwater Assessment in Wadi Bany Omair, Holy Makkah Area, Saudi Arabia," Egypt. Geophys. Soc. J., vol. 6, no. 67-79, 2008.

[5] A. Satriani, A. Loperte, V. Imbrenda, and V. Lapenna, "Geoelectrical surveys for characterization of the coastal saltwater intrusion in metapontum forest reserve (Southern Italy)," Int. J. Geophys., 2012, doi: 10.1155/2012/238478.

[6] J. S. Kayode, A. O. Adelusi, M. N. M. Nawawi, M. Bawallah, and T. S. Olowolafe, "Geo-electrical investigation of near surface conductive structures suitable for groundwater accumulation in a resistive crystalline basement environment: A case study of Isuada, southwestern Nigeria," J. African Earth Sci., vol. 119, pp. 289-302, 2016, doi: 10.1016/j.jafrearsci.2016.04.009.

[7] K. A. Mogaji and O. B. Omobude, "Modeling of geoelectric parameters for assessing groundwater potentiality in a multifaceted geologic terrain, Ipinsa Southwest, Nigeria - A GIS-based GODT approach," NRIAG J. Astron. Geophys., vol. 6, pp. 434-451, 2017, doi: 10.1016/j.nrjag.2017.07.001.

[8] M. I. I. Mohamaden and D. Ehab, "Application of electrical resistivity for groundwater exploration in Wadi Rahaba, Shalateen, Egypt," NRIAG J. Astron. Geophys., vol. 6, pp. 201-209, 2017, doi: 10.1016/j.nrjag.2017.01.001.

[9] M. I. I. Mohamaden, S. Abuo Shagar, and G. A. Allah, "Geoelectrical survey for groundwater exploration at the Asyuit governorate, Nile Valley, Egypt," J. King Abdulaziz Univ. Mar. Sci., vol. 20, pp. 91-108, 2009, doi: 10.4197/Mar.20-1.7.

[10] H. Y. Ali, C. P. Priju, and N. B. N. Prasad, "Delineation of Groundwater Potential Zones in Deep Midland Aquifers Along Bharathapuzha River Basin, Kerala Using Geophysical Methods," Aquat. Procedia, vol. 4, pp. 1039-1046, 2015, doi: 10.1016/j.aqpro.2015.02.131.

[11] A. M. S. Abd El-Gawad, A. D. M. Kotb, and G. H. G. Hussien, "Geoelectrical contribution for delineation the groundwater potential and subsurface structures on Tushka Area, Egypt," NRIAG J. Astron. Geophys., vol. 6, pp. 379-394, 2017, doi: 10.1016/j.nrjag.2017.10.003.

[12] T. C. Amin, Sidarto, S. Santosa, and W. Gunawan, The Geology of the Kotaagung Quadrangle, Sumatra, Scale 1:250 000. Bandung, Indonesia: Geological Research and Development Centre, 1994.

[13] S. A. Mangga, Amirudin, T. Suwarti, S. Gafoer, and Sidarto, Geological Map of Tanjungkarang, Sumatra. Bandung: Geological Research and Development Centre, 1993.

[14] I. G. B. Darmawan, L. D. Setijadji, and D. Wintolo, "Geology and Geothermal System in Rajabasa Volcano South Lampung Regenc , Indonesia (Approach to Field Observations , Water 
Geochemistry and Magnetic Method )," World Geotherm. Congr. 2015, 2015.

[15] N. Haerudin, A. Zaenudin, Y. Aribowo, and I. G. B. Darmawan, "Mapping and analysis of the physical properties of rocks for building materials in the Sunda Strait region," in Journal of Physics: Conference Series, 2018, doi: 10.1088/17426596/1080/1/012035.

[16] L. Song, J. Zhu, Q. Yan, and H. Kang, "Estimation of groundwater levels with vertical electrical sounding in the semiarid area of South Keerqin sandy aquifer, China," J. Appl. Geophys., 2012, doi: 10.1016/j.jappgeo.2012.03.011.

[17] E. Faleiro, G. Asensio, and J. Moreno, "Improved measurements of the apparent resistivity for small depths in Vertical Electrical Soundings," J. Appl. Geophys., 2016, doi: 10.1016/j.jappgeo.2016.05.016.

[18] M. G. Atwia, M. M. Abu-Heleika, and M. M. ElHoriny, "Hydrogeochemical and Vertical Electrical Soundings for Groundwater Investigations, Burg ElArab Area, Northwestern Coast of Egypt," J. African Earth Sci., 2013, doi: 10.1016/j.jafrearsci.2012.11.001.

[19] T. H. Abdel Hafeez, H. S. Sabet, A. N. El-Sayed, and M. A. Zayed, "Geoelectrical exploration of groundwater at West Dayrout Area, Assiut Governorate, Egypt," NRIAG J. Astron. Geophys., 2018, doi: 10.1016/j.nrjag.2018.07.004.
[20] M. H. Khalil, "Geoelectric resistivity sounding for delineating salt water intrusion in the Abu Zenima area, west Sinai, Egypt," J. Geophys. Eng., 2006, doi: 10.1088/1742-2132/3/3/006.

[21] M. Oladunjoye and S. Jekayinfa, "Efficacy of hummel (Modified Schlumberger) arrays of vertical electrical sounding in groundwater exploration: Case study of parts of ibadan metropolis, southwestern nigeria," Int. J. Geophys., 2015, doi: $10.1155 / 2015 / 612303$

[22] A. Atzemoglou and P. Tsourlos, "2D interpretation of vertical electrical soundings: Application to the Sarantaporon basin (Thessaly, Greece)," J. Geophys. Eng., 2012, doi: 10.1088/1742-2132/9/1/006.

[23] A. G. A. El_Hameed, H. M. El-Shayeb, N. A. ElAraby, and M. G. Hegab, "Integrated geoelectrical and hydrogeological studies on Wadi Qena, Egypt," NRIAG J. Astron. Geophys., 2017, doi: 10.1016/j.nrjag.2017.03.003.

[24] A. P. Aizebeokhai, A. I. Olayinka, and V. S. Singh, "Application of 2D and 3D geoelectrical resistivity imaging for engineering site investigation in a crystalline basement terrain, southwestern Nigeria," Environ. Earth Sci., vol. 61, pp. 1481-1492, 2010, doi: 10.1007/s12665-010-0464-z.

[25] W. M. Telford, L. P. Geldart, and R. E. Sheriff, Applied geophysics. 2nd edition. New York, USA: Cambridge University Press, 1990. 